\title{
Disparitas Pidana Terhadap Pelaku Kasus Tindak Pidana Penganiayaan
}

\author{
Rahmi Zilvia, Haryadi \\ Fakultas Hukum, Universitas Jambi \\ Author's email correspondence: rahmizilfia@gmail.com
}

\section{ABSTRAK}

Penelitian ini bertujuan untuk menganalisis mengenai dasar pertimbangan hakim dalam menjatuhkan pidana terhadap pelaku tindak pidana penganiayaan. Penelitian ini bersifat penelitian yuridis empiris. Berdasarkan hasil penelitian disimpulkan bahwa telah terjadi disparitas pidana. Disparitas pidana terjadi karena hakim belum mempertimbangkan fakta persidangan tentang akibat dari perbuatan pidana. Pada Kasus pertama tindak pidana mengakibatkan luka ringan dan tanpa senjata tajam. Kasus kedua tindak pidana mengakibatkan luka berat dengan menggunakan senjata tajam. Hakim menjatuhkan pidana penjara lebih berat pada kasus pertama yang seharusnya lebih ringan dari kasus kedua. Seharusnya hakim dalam menjatuhkan pidana hendaknya tidak hanya mempertimbangkan fakta yuridis, tetapi juga dengan cermat mempertimbangkan fakta persidangan dan fakta sosiologis.
\end{abstract}

\section{ARTICLE HISTORY}

Submission: 11 December 2019

Accepted: 04 February 2020

Publish: 07 February 2020

KEYWORDS: Corruption, returns losses, replacement money
Kata Kunci: Korupsi, pengembalian kerugian, uang pengganti.

\section{A. Pendahuluan}

Negara Indonesia adalah suatu Negara yang berdasarkan pada hukum atau Negara hukum. Pernyataan ini ditulis dalam Undang-Undang Dasar 1945 Amandemen ke-4 Pasal 1 ayat (3) menentukan: "Negara Indonesia adalah negara hukum". Hal ini membawa konsekuensi hukum bahwa dalam negara Indonesia, penyelenggaraan kekuasaan negara dalam arti luas harus dan senantiasa berdasar pada hukum, sebab hukum itulah yang memberi legitimasi sekaligus memberikan batas-batas yang menjadi wewenang negara (pemerintah). Disamping itu Pancasila dan UUD 1945 Pasal 27 ayat (2) menentukan: "Menjunjung tinggi hak asasi Manusia serta menjamin segala warga Negara bersamaan kedudukannya di dalam hukum dan pemerintahan itu dengan tidak ada pengecualian". 
Menurut Bahder Johan Nasution, Negara hukum (rechstaat), terdapat ciri-ciri sebagai berikut:

a. Adanya Undang-Undang Dasar atau Konstitusi yang memuat ketentuan tertulis tentang hubungan antara pengusaha dan rakyat

b. Adanya pemisahan kekuasaan Negara, yang meliputi: kekuasaan pembuat undangundang yang berada pada parlemen, kekuasaan kehakiman yang bebas dan merdeka, kekuasaan ini tidak hanya menangani sengketa antar individu rakyat, tetapi juga antara rakyat dengan penguasa dan pemerintah mendasarkan tindakannya atas undang-undang (wetmatig bestuur)

c. Diakuinya dan dilindunginya hak-hak rakyat yang sering disebut "vrijheidsrechten van burger". ${ }^{1}$

Mengenai ketentuan terkait penganiayaan, dapat melihat pada Pasal 351 - Pasal 358 Kitab Undang-Undang Hukum Pidana (KUHP). Mengenai yang dimaksud penganiayaan, tidak dijelaskan dalam KUHP. Pasal 351 KUHP hanya menyebutkan mengenai hukuman yang diberikan pada tindak pidana tersebut:

Pasal 351 KUHP:

(1) Penganiayaan diancam dengan pidana penjara paling lama dua tahun delapan bulan atau pidana denda paling banyak empat ribu lima ratus rupiah.

(2) Jika perbuatan mengakibatkan luka-luka berat, yang bersalah diancam dengan pidana penjara paling lama lima tahun.

(3) Jika mengakibatkan mati, diancam dengan pidana penjara paling lama tujuh tahun.

(4) Dengan penganiayaan disamakan sengaja merusak kesehatan.

(5) Percobaan untuk melakukan kejahatan ini tidak dipidana.

Penganiayaan dalam Pasal 351 KUHP, R. Soesilo dalam bukunya yang berjudul Kitab Undang-Undang Hukum Pidana (KUHP) Serta Komentar-Komentarnya Lengkap Pasal Demi Pasal, mengatakan bahwa undang-undang tidak memberi ketentuan apakah yang diartikan dengan "penganiayaan" itu. Menurut yurisprudensi, maka yang diartikan dengan "penganiayaan" yaitu sengaja menyebabkan perasaan tidak enak (penderitaan), rasa sakit, atau luka. Menurut alinea 4 pasal ini, masuk pula dalam pengertian penganiayaan ialah "sengaja merusak kesehatan orang". ${ }^{2}$

R. Soesilo dalam buku tersebut juga memberikan contoh dengan apa yang dimaksud dengan "perasaan tidak enak", "rasa sakit", "luka", dan "merusak kesehatan":

1. "perasaan tidak enak" misalnya mendorong orang terjun ke kali sehingga basah, menyuruh orang berdiri di terik matahari, dan sebagainya.

2. "rasa sakit" misalnya menyubit, mendupak, memukul, menempeleng, dan sebagainya.

3. "luka" misalnya mengiris, memotong, menusuk dengan pisau dan lain-lain.

4. "merusak kesehatan" misalnya orang sedang tidur, dan berkeringat, dibuka jendela kamarnya, sehingga orang itu masuk angin.

Menurut R. Soesilo, tindakan-tindakan di atas, harus dilakukan dengan sengaja dan tidak dengan maksud yang patut atau melewati batas yang diizinkan. Umpamanya

1 Bahder Johan Nasution, Negara Hukum dan Hak Asasi Manusia, Mandar Maju, Jambi, 2014, hlm. 6.

2 https://www.hukumonline.com/klinik/detail/ulasan/lt515867216deba/perbuatanperbuatan-yang-termasuk-penganiayaan/. Diakses pada tanggal 30 Januari 2020 
seorang dokter gigi mencabut gigi dari pasiennya. Sebenarnya ia sengaja menimbulkan rasa sakit, akan tetapi perbuatannya itu bukan penganiayaan, karena ada maksud baik (mengobati). Seorang bapa dengan tangan memukul anaknya di arah pantat, karena anak itu nakal. Inipun sebenarnya sengaja menyebabkan rasa sakit, akan tetapi perbuatan itu tidak masuk penganiayaan, karena ada maksud baik (mengajar anak). Meskipun demikian, maka kedua peristiwa itu apabila dilakukan dengan "melewati batas-batas yang diizinkan", misalnya dokter gigi tadi mencabut gigi sambil bersenda gurau dengan isterinya, atau seorang bapa mengajar anaknya dengan memukul memakai sepotong besi dan dikenakan di kepalanya maka perbuatan ini dianggap pula sebagai penganiayaan. ${ }^{3}$

Dalam kaitannya, kasus penganiayaan juga sering terjadi disparitas Pidana pada putusan-putusan hakim Terhadap Pelaku Kasus Tindak Pidana Penganiayaan. Disparitas merupakan bentuk dari ketidakadilan yang dilakukan hakim kepada para pencari keadilan, masyarakat tentunya akan membandingkan putusan hakim secara general dan menemukan bahwa disparitas telah terjadi dalam penegakan hukum di Indonesia. Disparitas pidana adalah penerapan pidana yang tidak sama terhadap tindak pidana yang sama (same offence) atau terhadap tindak-tindak pidana yang sifat berbahayanya dapat diperbandingkan (offences of comparable seriousness) tanpa dasar pembenaran yang jelas. Berdasarkan kenyataan, penegakan hukum pidana sehari-hari, disparitas tumbuh dan menyejarah dalam penegakan hukum di Indonesia. Disparitas tidak hanya terjadi pada tingkat keseriusan dari suatu perkara pidana yang sama, namun juga pada tingkat keseriusan dari suatu perkara pidana dan putusan hakimbaik satu majelis maupun oleh majelis yang berbeda terhadap perkara yang sama. "Dari segi hukum pidana maka kepentingan masyarakat lebih diutamakan dari kepentingan orang seorang (individu), yang dalam kehidupan sehari-hari disebut kepentingan umum". ${ }^{4}$

Penjatuhan pidana yang berbeda kemudian menjadi permasalahan tersendiri dalam penegakan hukum di Indonesia. Di satu sisi penjatuhan pidana yang tidak sama atau disparitas merupakan bentuk dari diskresi hakim dalam menjatuhkan putusan, namun di sisi lain penjatuhan pidana yang tidak sama pun menimbulkan ketidakpuasan bagi siterpidana sendiri maupun masyarakat. Model pemidanaan yang diatur dalam perundang-undangan (perumusan sanksi pidana maksimal) juga ikut memberi andil, dalam menjatuhkan putusan, hakim tidak boleh diintervensi pihak manapun. UU No. 48 Tahun 2009 tentang Kekuasaan Kehakiman menyebutkan hakim wajib menggali, mengikuti, dan memahami nilai-nilai hukum dan rasa keadilan yang hidup dalam masyarakat dan hakim juga wajib mempertimbangkan sifat baik dan jahat pada diri terdakwa.

Dalam pidato pengukuhanya sebagai Guru Besar Falkutas Hukum Universitas Hukum Universitas Indonesia, Harkristuti Harkrisnowo menyatakan: "berkenaan dengan perbedaan penjatuhan pidana untuk kasus yang serupa atau setara keseriusannya, tanpa alasan atau pembenaran yang jelas disebut dengan disparitas pidana”.

Ibid.

Leden Marpaung, Proses Penanganan Perkara Pidana (Penyelidikan dan Penyidikan), Edisi Kedua, Sinar Grafika, Jakarta, 2014, hlm. 20. 
Dalam tindak pidana penganiayaan juga terjadi suatu disparitas. Secara umum tindak pidana terhadap tubuh disebut penganiayaan, dan diatur dalam KUHP terdiri dari:

1. Penganiayaan sebagaimana yang diatur pada Pasal 351 KUHP yang terdiri dari:
a. Penganiayaan biasa
b. Penganiayaan yang mengakibatkan luka berat
c. Penganiayaan yang menyebabkan matinya orang

2. Penganiayaan ringan sebagaimana yang diatur pada Pasal 352 KUHP.

3. Penganiayaan berencana pada Pasal 353 KUHP terdiri dari:

a. Yang menyebabkan luka berat

b.Yang menyebabkan matinya orang

4. Penganiayaan berat pada Pasal 354 KUHP terdiri dari:

a. Yang menyebabkan luka berat

b. Yang menyebabkan matinya orang

5. Penganiayaan berat yang direncanakan diatur pada Pasal 355 KUHP terdiri dari:

a. Penganiayaan berat dan berencana

b. Penganiayaan berat dan berencana yang menyebabkan matinya orang.

Yang termasuk Pasal 351 ayat (1), bukan penganiayaan ringan, bukan penganiayaan berat atau berencana dan pula tidak mengakibatkan luka berat atau matinya orang. Pasal 351 hanya mengatakan bahwa penganiayaan dihukum dengan hukuman penjara selama-lamanya dua tahun delapan bulan atau denda sebanyakbanyaknya tiga ratus rupiah. Namun, disini penulis fokuskan hanya satu jenis penganiayaan saja, yaitu Pasal 351 ayat (1) KUHP "Penganiayaan Biasa".

Adapun putusan yang menjadi contoh kasus tindak pidana penganiayaan yang diproleh penulis dari Pengadilan Negeri Sengeti dalam kurun waktu tahun 2017-2018 adalah sebagai berikut:

Tabel

Data Perkara Tindak Pidana Penganiayaan

Di Pengadilan Negeri Sengeti (Tahun 2017-2018)

\begin{tabular}{|c|c|c|c|c|}
\hline No & Nomor Putusan & $\begin{array}{c}\text { Pasal Yang } \\
\text { Didakwakan }\end{array}$ & Tuntutan & Putusan \\
\hline 1. & $\begin{array}{c}\text { 169/Pid.B/2018/PN } \\
\text { snt }\end{array}$ & $\begin{array}{c}\text { Pasal } 351 \\
\text { ayat (1) } \\
\text { KUHP }\end{array}$ & $\begin{array}{c}1 \text { Tahun } 8 \\
\text { Bulan } \\
\text { penjara }\end{array}$ & $\begin{array}{c}1 \text { Tahun 4Bulan } \\
\text { penjara }\end{array}$ \\
\hline 2 & $\begin{array}{c}\text { 149/Pid.B/2018/PN } \\
\text { snt }\end{array}$ & $\begin{array}{l}\text { Pasal } 351 \text { ayat } \\
\text { (1) KUHP }\end{array}$ & $\begin{array}{l}2 \text { Tahun } \\
\text { penjara }\end{array}$ & $\begin{array}{l}\text { Pidana Penjara } 1 \\
\text { Tahun } 3 \text { Bulan }\end{array}$ \\
\hline 3. & $\begin{array}{c}\text { 67/Pid.B/2018/PN } \\
\text { snt }\end{array}$ & $\begin{array}{l}\text { Pasal } 351 \text { ayat } \\
\text { (1) KUHP }\end{array}$ & $\begin{array}{l}5 \text { Bulan } \\
\text { penjara }\end{array}$ & 4 Bulan penjara \\
\hline 4. & $\begin{array}{c}\text { 50/Pid.B/2018/PN } \\
\text { snt }\end{array}$ & $\begin{array}{l}\text { Pasal } 351 \text { ayat } \\
\text { (1) KUHP }\end{array}$ & $\begin{array}{l}6 \text { Bulan } \\
\text { penjara }\end{array}$ & 6 Bulan penjara \\
\hline 5. & $\begin{array}{l}\text { 210/Pid.B/2017/PN } \\
\text { snt }\end{array}$ & $\begin{array}{l}\text { Pasal } 351 \text { ayat } \\
\text { (1) KUHP }\end{array}$ & $\begin{array}{l}7 \text { Bulan } \\
\text { penjara }\end{array}$ & 5 Bulan penjara \\
\hline
\end{tabular}




\section{201/Pid.B/2017/PN Pasal $351 \quad 5$ Bulan 3 Bulan penjara snt ayat (1) penjara \\ KUHP}

\begin{tabular}{|c|c|c|c|c|}
\hline 7. & $\begin{array}{c}\text { 199/Pid.B/2017/PN } \\
\text { snt }\end{array}$ & $\begin{array}{c}\text { Pasal } 351 \text { ayat } \\
\text { (1) KUHP }\end{array}$ & $\begin{array}{l}1 \text { Bulan } \\
\text { penjara }\end{array}$ & 11 Bulan penjara \\
\hline 8. & $\begin{array}{c}\text { 178/Pid.B/2017/PN } \\
\text { snt }\end{array}$ & $\begin{array}{c}\text { Pasal } 351 \text { ayat } \\
\text { (1) KUHP }\end{array}$ & $\begin{array}{l}2 \text { Bulan } \\
\text { penjara }\end{array}$ & 2 Bulan penjara \\
\hline 9. & $\begin{array}{c}\text { 166/Pid.B/2017/PN } \\
\text { snt }\end{array}$ & $\begin{array}{c}\text { Pasal } 351 \text { ayat } \\
\text { (1) KUHP }\end{array}$ & $\begin{array}{l}6 \text { Bulan } \\
\text { penjara }\end{array}$ & 5 Bulan penjara \\
\hline 10. & $\begin{array}{c}\text { 163/Pid.B/2017/PN } \\
\text { snt }\end{array}$ & $\begin{array}{c}\text { Pasal } 351 \text { ayat } \\
\text { (1) KUHP }\end{array}$ & $\begin{array}{l}8 \text { Bulan } \\
\text { penjara }\end{array}$ & $\begin{array}{l}4 \text { Bulan } 15 \text { Hari } \\
\text { penjara }\end{array}$ \\
\hline 11. & $\begin{array}{c}\text { 143/Pid.B/2017/PN } \\
\text { snt }\end{array}$ & $\begin{array}{c}\text { Pasal } 351 \text { ayat } \\
\text { (1) KUHP }\end{array}$ & $\begin{array}{l}5 \text { Bulan } \\
\text { penjara }\end{array}$ & $\begin{array}{c}2 \text { Bulan } 15 \text { Hari } \\
\text { kurungan }\end{array}$ \\
\hline 12. & $\begin{array}{c}\text { 94/Pid.B/2017/PN } \\
\text { snt }\end{array}$ & $\begin{array}{c}\text { Pasal } 351 \text { ayat } \\
\text { (1) KUHP }\end{array}$ & $\begin{array}{l}6 \text { Bulan } \\
\text { penjara }\end{array}$ & 4 Bulan penjara \\
\hline 13. & $\begin{array}{c}\text { 70/Pid.B/2017/PN } \\
\text { snt }\end{array}$ & $\begin{array}{c}\text { Pasal } 351 \text { ayat } \\
\text { (1) KUHP }\end{array}$ & $\begin{array}{l}6 \text { Bulan } \\
\text { penjara }\end{array}$ & 5 Bulan penjara \\
\hline 14. & $\begin{array}{c}\text { 66/Pid.B/2017/PN } \\
\text { snt }\end{array}$ & $\begin{array}{c}\text { Pasal } 351 \text { ayat } \\
\text { (1) KUHP }\end{array}$ & $\begin{array}{c}1 \text { Tahun } 6 \\
\text { Bulan penjara }\end{array}$ & $\begin{array}{c}1 \text { Tahun } 4 \text { Bulan } \\
\text { penjara }\end{array}$ \\
\hline 15. & $\begin{array}{c}\text { 57/Pid.B/2017/PN } \\
\text { snt }\end{array}$ & $\begin{array}{c}\text { Pasal } 351 \text { ayat } \\
\text { (1) KUHP }\end{array}$ & $\begin{array}{l}4 \text { Bulan } \\
\text { penjara }\end{array}$ & 2 Bulan penjara \\
\hline 16. & $\begin{array}{c}\text { 48/Pid.B/2017/PN } \\
\text { snt }\end{array}$ & $\begin{array}{c}\text { Pasal } 351 \text { ayat } \\
\text { (1) KUHP }\end{array}$ & $\begin{array}{l}4 \text { Bulan } \\
\text { penjara }\end{array}$ & 2 Bulan penjara \\
\hline 17. & $\begin{array}{c}\text { 47/Pid.B/2017/PN } \\
\text { snt }\end{array}$ & $\begin{array}{c}\text { Pasal } 351 \text { ayat } \\
\text { (1) KUHP }\end{array}$ & $\begin{array}{l}4 \text { Bulan } \\
\text { penjara }\end{array}$ & 2 Bulan penjara \\
\hline 18. & $\begin{array}{c}\text { 27/Pid.B/2017/PN } \\
\text { snt }\end{array}$ & $\begin{array}{c}\text { Pasal } 351 \text { ayat } \\
\text { (1) KUHP }\end{array}$ & $\begin{array}{l}1 \text { Tahun } \\
\text { penjara }\end{array}$ & 7 Bulan penjara \\
\hline
\end{tabular}

Sumber: Pengadilan Negeri Sengeti

Kasus di atas adalah kasus tindak pidana penganiayaan Pasal 351 ayat (1) KUHP yang menegaskan bahwa:

(1) Penganiayaan diancam dengan pidana penjara paling lama dua tahun delapan bulan atau pidana denda paling banyak empat ribu lima ratus rupiah.

(2) Jika perbuatan mengakibatnya luka-luka berat, yang bersalah diancam dengan pidana penjara paling lama lima tahun.

(3) Jika mengakibatkan mati, diancam dengan pidana penjara paling lama tujuh tahun.

(4) Dengan penganiayaan disamakan sengaja merusak kesehatan.

(5) Percobaan untuk melakukan kejahatan ini tidak dipidana.

Dari beberapa kasus di atas yang perkaranya sama dan penjatuhan pidananya yang berbeda, penulis merasa tertarik dengan perkara Nomor 169/Pid.B/2018/PN snt dan perkara Nomor 201/Pid.B/2017/PN snt.

1. Pada putusan Nomor 169/Pid.B/2018/PN snt, bahwa Terdakwa HARIYANTO L Als KIRUN Bin LISWANTO pada hari Senin tanggal 30 April 2018 sekitar pukul 03.00 
WIB atau setidak-tidaknya pada suatu waktu yang masih termasuk dalam bulan April tahun 2018, bertempat di Jalan Poros antara Desa Suka Makmur Unit I menuju Desa Panca Bakti Unit V Kec. Sungai Bahar Kab. Muaro Jambi atau setidaktidaknya disuatu tempat lain yang masih termasuk dalam daerah hukum Pengadialn Negeri Sengeti, dengan sengaja melakukan penganiayaan atau menimbulkan rasa sakit atau luka, terdakwa memukul wajah saksi korban DEDY SATRIA PURBA Bin SUHERMAN PURBA sebelah kiri dengan menggunakan tangan kanan secara berulang kali dan memegang kerah terdakwa baju dengan menggunakan tangan sebelah kiri, didakwa dengan Pasal 351 ayat (1) KUHP. Akibat dari perbuatan tersebut Penuntut Umum menuntut terdakwa dengan pidana penjara 1 (satu) tahum 8 (delapan) bulan kemudian Hakim menjatuhkan pidana penjara selama 1 (satu) tahun 4 (empat) bulan.

2. Pada putusan Nomor 201/Pid.B/2017/PN snt, bahwa terdakwa KAMERSON LIMBONG Bin J. LIMBONG, pada hari minggu tanggal 10 September 2017 sekira pukul 02.00 WIB atau setidak-tidaknya pada suatu waktu dalam bulan September tahun 2017 atau setidak-tidaknya pada waktu lain pada tahun 2017, bertempat di Jalan Lintas Timur Desa Suko Awin Jaya, Kec. Sekernan Kab. Muaro Jambi atau setidak-tidaknya pada suatu tempat yang masih termasuk dalam daerah hukum Pengadilan Negeri Sengeti yang berwenang memeriksa dan mengadili perkara ini, dengan sengaja menyebabkan rasa tidak enak, penderitaan atau rasa sakit, luka atau merusak kesehatan orang atau melakukan penganiayaan, terdakwa memeukul kepala sakasi korban sebanyak kurang lebih 2 (dua) kali setelah itu terdakwa menyeret sakasi korban ke arah atas dekat simpang di sebuah warung sambil berjalan kaki dan sesampainya di sana terdakwa memukul kembali kepala sakasii korban sebanyak 1 (satu) kali, didakwa dengan Pasal 351 ayat (1). Akibat dari perbuatan tersebut Penuntut Umum menuntut terdakwa dengan pidana penjara 5 (lima) bulan kemudian Hakim menjatuhkan pidana penjara selama 3 (tiga) bulan.

Dari kasus di atas dapat dilihat perbedaan mencolok terhadap penjatuhan pidana yang berbeda untuk tindak pidana yang sama. Kedua kasus di atas terbukti secara sah dan menyakinkan melakukan tindak pidana penganiayaan yang mengakibatkan korban mengalami luka-luka ringan, dalam disparitas penjatuhan pidana ini berakibat buruk, terpidana akan membandingkan pidananya dengan terpidana lain akan merasa adanya penjatuhan pidana, hal ini dapat berakibat terpidana memandang dirinya sebagai korban ketidakadilan hukum. Dan berdasarkan pada latar belakang masalah yang telah dijelaskan di atas menjadi faktor yang mendorong penulis untuk mengangkat judul, "DISPARITAS PIDANA TERHADAP PELAKU TINDAK PIDANA PENGANIAYAAN"

Disparitas pidana merupakan bentuk dari ketidakadilan yang dilakukan hakim kepada para pencari keadilan.

Menurut Harkristuti Harkrisnowo disparitas pidana dipersepsi oleh publik sebagai bukti ketiadaan keadilan (societtal justice). Secara yuridis formal, keadaan seperti ini tidak dapat dipandang sudah bertentangan dengan hukum. Terkadang, sering kali orang tidak ingat bahwa elemen keadilan pada pokoknya harus melekat pada putusan yang dijatuhkan oleh hakim. Menurutnya, disparitas pidana dapat terjadi dalam beberapa kategori yaitu: 
1) Disparitas antara tindak pidana yang sama;

2) Disparitas antara tindak pidana yang mempunyai tingkat keseriusan yang sama;

3) Disparitas pidana yang dijatuhkan oleh pelaku yang sama;

4) Disparitas antara pidana yang dijatuhkan oleh majelis hakim yang berbeda untuk tindak pidana yang sama.

Masyarakat tentunya akan membandingkan putusan hakim secara general dan menemukan bahwa disparitas telah terjadi penegakkan hukum di Indonesia. Disparitas pidana ini pun membawa problematika tersendiri dalam penegakan hukum di Indonesia. Di satu sisi pemidanaan yang berbeda/disparitas pidana merupakan bentuk dari diskresi hakim dalam menjatuhkan putusan, tapi di sisi lain pemidanaan yang berbeda atau disparitas pidana ini pun membawa ketidakpuasan bagi terpidana bahkan masyarakat pada umumnya.

Tindak pidana atau perbuatan yang dapat dihukum atau delik adalah perbuatan yang melanggar undang-undang dan oleh karena itu bertentangan dengan undangundang yang dilakukan dengan sengaja oleh orang yang dapat dipertanggungjawabkan, untuk dapat membedakan suatu perbuatan tindak pidana atau yang bukan tindak pidana ialah apakah perbuatan tersebut diberi sanksi pidana atau tidak diberi sanksi pidana.

Pada Pasal 351 KUHP menentukan bahwa: "penganiayaan dihukum dengan hukuman penjara selama-lamanya yaitu dua tahun delapan bulan atau denda sebanyak-banyaknya empat ribu lima ratus rupiah". Penganiayaan tidak menunjuk pada salah satu bentuk perbuatan, unsur dari penganiayaan adalah rasa sakit atau luka yang dihendaki oleh si pelaku itu sendiri atau harus adanya unsur kesengajaan dan melawan hukum harus ada.

Ada tiga golongan utama untuk membenarkan penjatuhan pidana:

1. Teori Absolut (teori pembalasan)

Teori absolut menentukan bahwa pidana tujuannya bukanlah untuk praktis, misalnya memperbaiki pelaku kejahatan. Kejahatan itu sendiri yang mengandung unsur-unsur untuk dikenakan pidana, adanya pidana karena suatu kejahatan sudah dilakukan. Tidak perlu untuk memikirkan manfaat pemidanaan tersebut dan setiap tindak pidana mempunyai konsekuensi terhadap pelakunya yaitu harus dijatuhkan pidana. Tujuan pemidanaan dalam ajaran absolut ini memang jelas sebagai pembalasan, tetapi cara bagaimana pidana tersebut dapat dibenarkan kurang jelas, karena dalam ajaran ini tidak dijelaskan mengapa harus dianggap adil meniadakan rasa terganggunya masyarakat dengan cara menjatuhkan penderitaan terhadap seseorang yang melakukan kejahatan. Tindakan Pembalasan di dalam penjatuhan pidana mempunyai dua arah yaitu:

a. Ditujukan pada penjahatnya (sudut subyektif dari pembalasan)

b. Ditujukan untuk memenuhi kepuasan dari perasaan dendam di kalangan masyarakat (sudut obyektif dari pembalasan)

2. Teori Relatif (Teori Tujuan)

Teori relatif mencari dasar hukum pidana dalam menyelenggarakan tertib masyarakat dan akibatnya yaitu tujuan untuk prevensi terjadinya kejahatan. Menurut teori ini suatu kejahatan tidak mutlak harus diikuti dengan suatu pidana. Untuk ini, tidaklah cukup adanya suatu kejahatan, tetapi harus dipersoalkan perlu dan 
manfaatnya suatu pidana dilihat pada masa lampau, tetapi juga pada masa depan. Tujuan ini pertama-tama harus diarahkan kepada upaya agar di kemudian hari kejahatan yang telah dilakukan itu tidak terulang lagi (prevensi). Dalam teori relatif penjatuhan pidana tergantung dari efek yang diharapkan dari penjatuhan pidana itu sendiri, yakni agar seseorang tidak mengulangi perbuatannya. Hukum pidana difungsikan sebagai ancaman sosial dan psikis. Hal tersebut menjadi satu alasan mengapa hukum pidana kuno mengembangkan sanksi pidana yang begitu kejam dan pelaksanaannya harus dilakukan di muka umum, yang tidak lain bertujuan untuk memberikan ancaman kepada masyarakat luas.

\section{Teori Gabungan}

Dalam teori ini titik beratnya pada keadilan mutlak yang berwujudkan adanya pembalasan, namun pembalasan tersebut yang berguna bagi masyarakat itu sendiri. Dasar dari pidana adalah penderitaan yang sesuai dengan perbuatan yang dilakukan oleh pelaku tindak pidana. Tetapi sampai batas mana beratnya pidana dan beratnya perbuatan yang dilakukan oleh pelaku tindak pidana. Titik tolak dari ajaran ini, sebagaimana dianut oleh Hugo Grotius, adalah bahwa siapa yang berbuat kejahatan, maka ia akan terkena derita. Penderitaan dianggap wajar diterima oleh pelaku kejahatan, tetapi manfaat sosial akan mempengaruhi berat-ringannya derita yang layak dijatuhkan. Sejalan dengan pandangan tersebut, M.P. Rossi menyatakan bahwa selain pembalasan, prevensi umum juga dianggap tujuan penting dalam hukum pidana. Karena kita hidup dalam masyarakat yang tidak sempurna dan tidak mungkin juga untuk menuntut keadilan yang absolut, maka dapat kiranya kita mencukupkan diri dengan pemidanaan yang dilandaskan pada tertib sosial yang tidak sempurna tersebut. Dengan kata lain penerapan hukum pidana yang manusiawi dibatasi oleh syarat-syarat yang dituntut oleh masyarakat.

\section{B. METODE PENELITIAN}

Tipe penelitian ini adalah tipe penelitian normatif, yaitu penelitian yang dilakukan atau dituju hanya pada peraturan-peraturan tertulis atau bahan-bahan hukum terdiri dari bahan primer meliputi peraturan perundangan, bahan hukum sekunder terdiri dari buku, jurnal, dan literatur lainnya.

\section{PEMBAHASAN}

\section{Pertimbangan Hakim Dalam Menjatuhkan Pidana Terhadap Pelaku Tindak Pidana Penganiayaan}

Jaksa Penuntut Umum Kejaksaan Negeri Sengeti mendakwa dengan dakwaan melanggar Pasal 351 ayat (1) KUHP yang menyatakan "Penganiayaan diancam dengan pidana penjara paling lama dua tahun delapan bulan atau denda paling banyak empat ribu lima ratus rupiah".

Jaksa Penuntut Umum menuntut terdakwa dengan 1 (satu) tahun 8 (delapan) bulan pidana penjara, dan di putus oleh Hakim Pengadilan Negeri Sengeti dengan pidana penjara selama 1 (satu) tahun 4 (empat) bulan.

Sebelum hakim menjatuhkan pidana terhadap terdakwa, perlu dipertimbangkan terlebih dahulu hal-hal yang memberatkan dan hal-hal yang meringankan, yaitu:

Keadaan yang memberatkan: 
- Perbuatan terdakwa mengakibatkan saksi korban Dedy Satria Purba Bin Suherman Purba menjadi terluka;

- Perbuatan terdakwa meresahkan masyarakat;

Keadaan yang meringankan:

- Terdakwat terus terang mengakui perbuatannya dan merasa menyesal;

- Terdakwa bersikap sopan didepan persidangan;

\section{Perkara Nomor: 201/Pid.B/2017/PN Snt}

Jaksa Penuntut Umum Kejaksaan Negeri Sengeti dalam mendakwa dengan dakwaan melanggar Pasal 351 ayat (1) KUHP yang menyatakan "Penganiayaan diancam dengan pidana penjara paling lama dua tahun delapan bulan atau denda paling banyak empat ribu lima ratus rupiah".

Tuntutan Jaksa Penuntut Umum menuntut terdakwa dengan pidana penjara 5 (lima) bulan, dan di putus oleh Hakim Pengadilan Negeri Sengeti dengan pidana penjara selama 3 (tiga) bulan.

Sebelum hakim memutuskan pidana kepada terdakwa, terlebih dahulu harus mempertimbangkan hal-hal yang memberatkan dan hal-hal yang meringankan si terdakwa, yaitu:

Hal-hal yang memberatkan:

- Perbuatan siterdakwa menyebabkan saksi Refi Hidayat mengalami luka;

Keadaan yang meringankan:

- Terdakwa bersikap sopan dipersidangan;

- Terdakwa menyesali perbuatannya;

Dari kedua kasus diatas dapat disimpulkan bahwa penyebab adanya penjatuhan pidana yang berbeda, karena adanya perbedaan keadaan yang meringankan dan memberatkan pidana terhadap terdakwa. Berdasarkan kasus perkara nomor 169/Pid.B/2018/PN Snt, hakim menjatuhkan pidana penjara selama 1 tahun 4 bulan karena saksi korban mengalami luka robek di atas alis kiri, di kelopak mata kiri bagian atas dan di kelopak mata kiri bawah serta ditemukan luka lecet di lutut kiri bagian bawah, tungkal kiri bawah bagian belakang serta tampak kemerahan pada bagian putih bola mata kanan korban. Menurut penulis penjatuhan pidana oleh hakim terhadap kasus tersebut sudah tepat, karena hakim mempertimbangkan akibat perbuatan terdakwa terhadap korban. Sedangkan kasus nomor 201/Pid.B/2017/PN Snt, menurut penulis hukuman yang dijatuhkan oleh hakim yaitu pidana penjara selama 3 bulan belum tepat, karena korban merupakan kernet truk yang menabrak motor terdakwa. Korban tidak melakukan perbuatan atau kesalahan terhadap terdakwa karena yang mengendarai truk tersebut adalah rekan korban, korban hanya dijadikan pelampiasan amarah terdakwa akibat motor terdakwa ditabrak oleh supir truk yang melarikan diri setelah kejadian. Akibat dari penganiayaan yang dilakukan oleh terdakwa tersebut korban mengalami luka robek di kepala bagian kiri samping dengan ukuran $5 \mathrm{~cm}$, lebar $1 \mathrm{~cm}$ dan dalam $0,5 \mathrm{~cm}$, luka memar di pinggang kanan ukuran panjang $5 \mathrm{~cm}$, lebar $2 \mathrm{~cm}$ dengan kesimpulan luka tersebut akibat benda tumpul. Hukuman yang di jatuhkan hakim untuk terdakwa dengan nomor perkara 201/Pid.B/2017/PN Snt, menurut penulis tidak akan memberi efek jera terhadap terdakwa karena ringannya pidana yang dijatuhkan. Sedangkan kasus dengan nomor perkara 169/Pid.B/2018/PN Snt, hakim menjatuhkan pidana lebih berat terhadap 
terdakwa, sedangkan kedua kasus memiliki kesamaan dalam melakukan penganiayaan, para terdakwa sama-sama menggunakan tangan kosong untuk melukai korbannya.

\section{a. Pertimbangan Yuridis}

Pertimbangan Yuridis adalah pertimbangan hakim yang didasarkan pada fakta-fakta yuridis yang terungkap di dalam persidangan dan oleh undang-undang telah ditetapkan hal yang harus dimuat di dalam suatu putusan. Adapun pertimbangan hakim yang digolongkan sebagai pertimbangan yuridis secara sistematis akan diuraikan sebagai berikut:

\section{- Dakwaan Jaksa Penuntut Umum}

Perumusan dakwaan berdasarkan dari pemeriksaan, dan pada perkara Nomor 169/Pid.B/2018/PN Snt, dalam perkara ini dituntut oleh Jaksa Penuntut Umum dengan dakwaan tunggal yaitu Pasal 351 ayat (1) KUHP dan dalam perkara Nomor 201/Pid.B/2017/PN Snt, dalam perkara ini dituntut oleh Jaksa Penuntut Umum dengan dakwaan tunggal yaitu Pasal 351 ayat (1) KUHP.

Menurut penulis dalam dakwaan yang didakwakan oleh Jaksa Penuntut Umum terhadap kedua perkara tersebut telah sesuai karena telah memenuhi unsurunsur yang terdapat dalam Pasal 351 ayat (1) KUHP.

\section{b. Pertimbangan Fakta di Persidangan}

Menurut penulis berdasarkan fakta-fakta yang telah terungkap di dalam persidangan banyak terjadi kesesuaian antara keterangan terdakwa, keterangan saksi serta berupa alat bukti yang terungkap di persidangan, sehingga terhadap kedua perkara telah terbukti secara sah dan meyakinkan telah melakukan tindak pidanan penganiayaan, selain itu karena tidak ditemukannya alasan pemaaf dan pembenar dalam perkara penganiaayaan ini, jadi terhadap kedua kasus perkara tersebut dapat dijatuhi pidana, karena dalam fakta-fakta persidangan itu juga, jaksa penutut umum bisa membuktikan bahwa terdakwa memenuhi unsur-unsur dari Pasal yang didakwakan kepada terdakwa dalam surat dakawaan, sehingga tidak ada keraguan bagi hakim untuk memutus perkara ini.

\section{c. Pertimbangan Sosiologis}

Pertimbangan sosiologis dalam perkara ini, terdiri dari dua hal yaitu hal yang memberatkan dan meringankan yang bisa menjadi pertimbangan oleh hakim sebelum memutuskan perkara. Hal yang memberatkan merupakan sesuatu yang menjadi alasan sehingga terdakwa yang kenakan pidana menjadi jera ataupun menambahkan pidana yang dituntut oleh jaksa penuntut umum kepada terdakwa dikarenakan terdakwa tidak adanya hal yang meringankan. Hal yang meringankan menjadi alasan bagi hakim supaya saksi yang didakwakan dikurangi oleh majelis hakim dikarenakan terdakwa terdapat banyak hal yang meringakan terhadapnya, begitupun sebaliknya jika hal-hal yang memberatkan yang banyak maka juga akan menjadi pertimbangan hakim dalam memutuskan pidana bagi terdakwa.

\section{Simpulan}

Berdasarkan penelitian yang penulis lakukan pada perkara Nomor 169/Pid.B/2018/PN Snt dan Nomor 201/Pid.B/2017/PN Snt, maka dapat disimpulkan bahwa kedua perkara didakwa dengan dakwaan tunggal, dan kedua didakwa melanggar Pasal 351 ayat (1) KUHP. Dalam Putusan kedua perkara tersebut terdakwa 
menyesali perbuatannya dan tidak akan mengulanginya tetapi penjatuhan pidana untuk kedua perkara tersebut berbeda. Putusan nomor 201/Pid.B/2017/PN Snt lebih ringan dibandingkan dengan putusan nomor 169/Pid.B/2018/PN Snt. Penjatuhan pidana yang berbeda terhadap kasus yang sama akan menimbulkan ketidakpercayaan masyarakat terhadap hukum, karena terdakwa yang dijatuhi pidana lebih berat akan membandingkan hukuman tersebut terdakwa lain yang dijatuhi pidana lebih ringan, sehingga memunculkan anggapan bahwa terdakwa tersebut tidak mendapatkan keadilan hukum dan menimbulkan bisa disparitas pidana.

\section{DAFTAR PUSTAKA}

\section{Dokumen Hukum}

Undang-Undang Dasar Tahun 1945 Amandemen Ke-lima

Undang-Undang Nomor 1 Tahun 1946 Tentang Kitab Undang Hukum Pidana

Republik Indonesia, Undang-Undang Nomor 8 Tahun 1981 Tentang Hukum Acara Pidana.

Republik Indonesia, Undang-Undang Tentang Kekuasaan Kehakiman. Nomor 48 Tahun 2009 Tentang Kekuasaan Kehakiman. LNRI Nomor 157.Peraturan Menteri Kehakiman RI. Nomor M.03UM.01.06 Tahun 1983 Tentang Penetapan Lembaga Pemasyarakatan Tertentu sebagai Rumah Negara

\section{Buku}

Aminanto. Politik Hukum Pidana 1, Jember Katamedia, Jember, 2017.

Bahder Johan Nasution. Negara Hukum dan Hak Asasi Manusia, Mandar Maju, Jambi, 2014.

Bernard Arief Sidharta. Refleksi tentang Struktur Ilmu Hukum, Cet.pertama, Mandar Maju, Bandung, 1999.

Djisman Samosir. Hukum Acara Pidana, Cetakan Pertama, Nuansa Aulia, Bandung, 2018.

Leden Marpaung. Proses Penanganan Perkara Pidana (Penyelidikan dan Penyidikan), Edisi Kedua, Sinar Grafika, Jakarta, 2014.

Leden Marpaung. Tindak Pidana terhadap Nyawa dan Tubuh, Sinar Grafika, Jakarta, 2002

Muladi dan Bardar Nawawi Arief. Teori-Teori Kebijakan Hukum Pidana, Alumni, Bandung, 2005

Peter Muhammad Marzuki. Penelitian Hukum Pidana, Kencana, Jakarta, 2005

Waluyo, Bambang. Pidana dan Pemidanaan. Jakarta: Sinar Grafika, 2004. 
Wirjono Prodjodikoro. Asas-Asas Hukum Pidana di Indonesia, PT Refika Aditama, Bandung, 2003

Wirjono Prodjodikoro. Tindak-Tindak Pidana Tertentu di Indonesia, PT Refika Aditama, Bandung, 2003

\section{Jurnal}

Sahuri Lasmadi, Metode penelitian hukum mormatif, Majalah hukum forum akademika, Fakultas hukum universitas Jambi, 2006. 